Research Article

\title{
Data Analysis of the Factors Influencing the Industrial Land Leasing in Shanghai Based on Mathematical Models
}

\author{
Jing Cheng $\mathbb{B}$ \\ School of Architecture, Tsinghua University, Beijing 100084, China \\ Correspondence should be addressed to Jing Cheng; jingcheng7-c@my.cityu.edu.hk
}

Received 25 March 2020; Accepted 1 April 2020; Published 25 April 2020

Guest Editor: Ying Dai

Copyright ( 92020 Jing Cheng. This is an open access article distributed under the Creative Commons Attribution License, which permits unrestricted use, distribution, and reproduction in any medium, provided the original work is properly cited.

By analyzing the background of land leasing in Shanghai, the hypotheses of the mathematical models of industrial land leasing in Shanghai are proposed, and then, the mathematical models of the land price and land area are presented for analyzing the factors of industrial land leasing. Based on the mathematical models and the district data of Shanghai from 2007 to 2015, the factors influencing industrial land leasing by the district government are studied. It is shown that the influencing factors, such as the land area, GDP, tenure of district mayor, and the distance between the land and the nearest subway station, affect the government behavior on industrial land leasing.

\section{Introduction}

The development of industry is very important for the economics of a country. With rapid development of the economics in China, it is necessary to study the industrial land leasing in China.

For the industrial land uses, the local governments in China must consider the development of the economics of the city when leasing land, and it is important to study the factors that influence industrial land leasing by the government [1].

Shanghai is an international metropolis and the largest city in China. Studying the industrial land leasing in Shanghai will show the development of industry in the large cities in China, and with the gradual implementation of new urbanization plan in China, the mode of the industrial land leasing in Shanghai will offer a reference for the development of other new large cities.

The constraint of land availability affects urban economic growth, and the importance of land conversion in land leasing was explained [2]. With the rapid urban development, the demand for land use should be balanced by the governments, and the distribution of rural land and urban land should be considered [3]. The local public goods, such as transportation system, are very important for industry development of a city, and these will influence land prices and house prices. Transportation nodes and distance between the location of the land and the city center affect the land price in Shanghai [4]. Rail transit and mass transit can attract land development and expand the urbanization $[5,6]$. Public transit, high-quality schools, universities, and environmental amenities near the land can also affect the land price [7]. Proximity to the subway can increase the economic activities and consumer amenities [8]. Municipal governments in China establish subway stations in suburban districts to decrease the transportation cost of people and gain more revenues from future land transactions [9]. The subway system shows a positive effect on commercial property values in Wuhan in China [10]. The role of built, human, social, and natural capital can impact land values [11].

At present, most industrial land is leased by listing. The government policy and intention can affect the industrial land leasing greatly. The corresponding researches based on the district data need to be done for the large cities including Shanghai and Beijing.

In this paper, by analyzing the background of land leasing in Shanghai, the hypotheses of the mathematical models of industrial land leasing in Shanghai are proposed, and then, mathematical models of land price and land area 
are presented for analyzing the factors of industrial land leasing. Based on the mathematical models and the district data of Shanghai from 2007 to 2015, the factors influencing industrial land leasing by the district government are studied.

It is shown that the land area, GDP, and the distance between the land and Hongqiao International Airport have positive associations on the industrial land price. The mode of land leasing, the location of the district, paid-in foreign investment, unemployment, tenure of district mayor, gross industrial production, total industrial asset, the distances between the land and Shanghai Railway Station, the nearest subway station, the nearest entrance or exit of highway, and the nearest industrial park have negative associations on the industrial land price, and the number of entrances and exits of highways in the district and the location of the district have positive associations on the total industrial land area by the government in Shanghai. These factors can influence the government on making decisions to lease industrial land in Shanghai. This study will help the governments propose more efficient and sustainable land use policies and better land leasing decisions in the coming decades.

\section{Hypotheses of Mathematical Models of Industrial Land Leasing in Shanghai}

To present the mathematical models for the factors influencing industrial land leasing, 3 hypotheses are proposed in this paper.

Hypothesis 1. The land characteristics have significant influences on industrial land leasing by the government.

The land characteristics include the area of the land, floor ratio of the land, modes of land leasing, and location of the district.

The land area is a basic factor for land leasing. The floor area ratio of the land is the ratio of built area to land area. It is a very important factor associated with the land prices. The modes of land leasing, such as tender and listing, can affect land leasing and land prices [12]. In Shanghai, the districts are divided into three levels, including the center districts, suburban districts, and county, which are shown in Section 3. The location of the district affects land prices.

Hypothesis 2. The district characteristics have significant influences on industrial land leasing by the government.

The district characteristics include GDP of the district, tenure of district mayor, paid-in foreign investment, unemployment, gross industrial production, total industrial asset, and industrial employees.

GDP is associated with the economic development of the district, and it is one of the influencing factors of land leasing by the government decision in this research.

The district leaders, such as district mayor and the party secretary, can decide land leasing.

For industrial land use, attracting foreign investment is very important. The foreign investment affects the developments of economics and industry.
Unemployment is associated with the economic development of the district and the income of employees. Unemployment will decrease with the increase of the industrial land leasing.

Industrial characteristics reflect the state of an industry. They include gross industrial production, total industrial asset, and industrial employees. Moreover, they are considered as the factors influencing land leasing for industrial land use.

Hypothesis 3. The location characteristics have significant influences on industrial land leasing by the government.

The location characteristics include the distances of the land to city center, district center, airports, railway station, the nearest subway, the nearest highway, and the nearest industrial park.

People's Square is regarded as the city center of Shanghai, and the locations of the district governments are considered as the district centers.

Hongqiao International Airport and Pudong International Airport are considered as major airports in Shanghai. Shanghai Railway Station is regarded as the main railway station in Shanghai.

According to the Introduction section, subway is an important factor influencing land leasing, land prices, and house prices.

The newly completed highway affects the land value [13]. The less the distance between the distribution center and the nearest entrance or exit of highway is, the higher the rent is [14]. Thus, highways have a strong relationship with land value.

Industrial parks are very important for urban land use planning, and their locations depend on the accessibility and economic indicators [15].

These hypotheses consider different aspects, which are the variables to present mathematical models to analyze the factors influencing land leasing by the district government comprehensively.

\section{Data of Influencing Factors of Industrial Land Leasing in Shanghai}

There are 19 districts in Shanghai. Huangpu District, Xuhui District, Changning District, Jing'an District, Putuo District, Hongkou District, Yangpu District, Luwan District, and Zhabei District are the center districts of Shanghai; Minhang District, Baoshan District, Jiading District, Pudong New Area, Nanhui District, Jinshan District, Songjiang District, Qingpu District, and Fengxian District are the suburban districts of Shanghai; and Chongming District is the county of Shanghai. Figure 1 shows the distribution of 19 districts in Shanghai.

In this paper, the data of GDP, tenure of district mayor, paid-in foreign investment, unemployment, gross industrial production, total industrial asset, and industrial employees of 19 districts in Shanghai from 2007 to 2015 are collected. The district data are collected from yearbooks of Shanghai and districts of Shanghai from 2007 to 2015. 


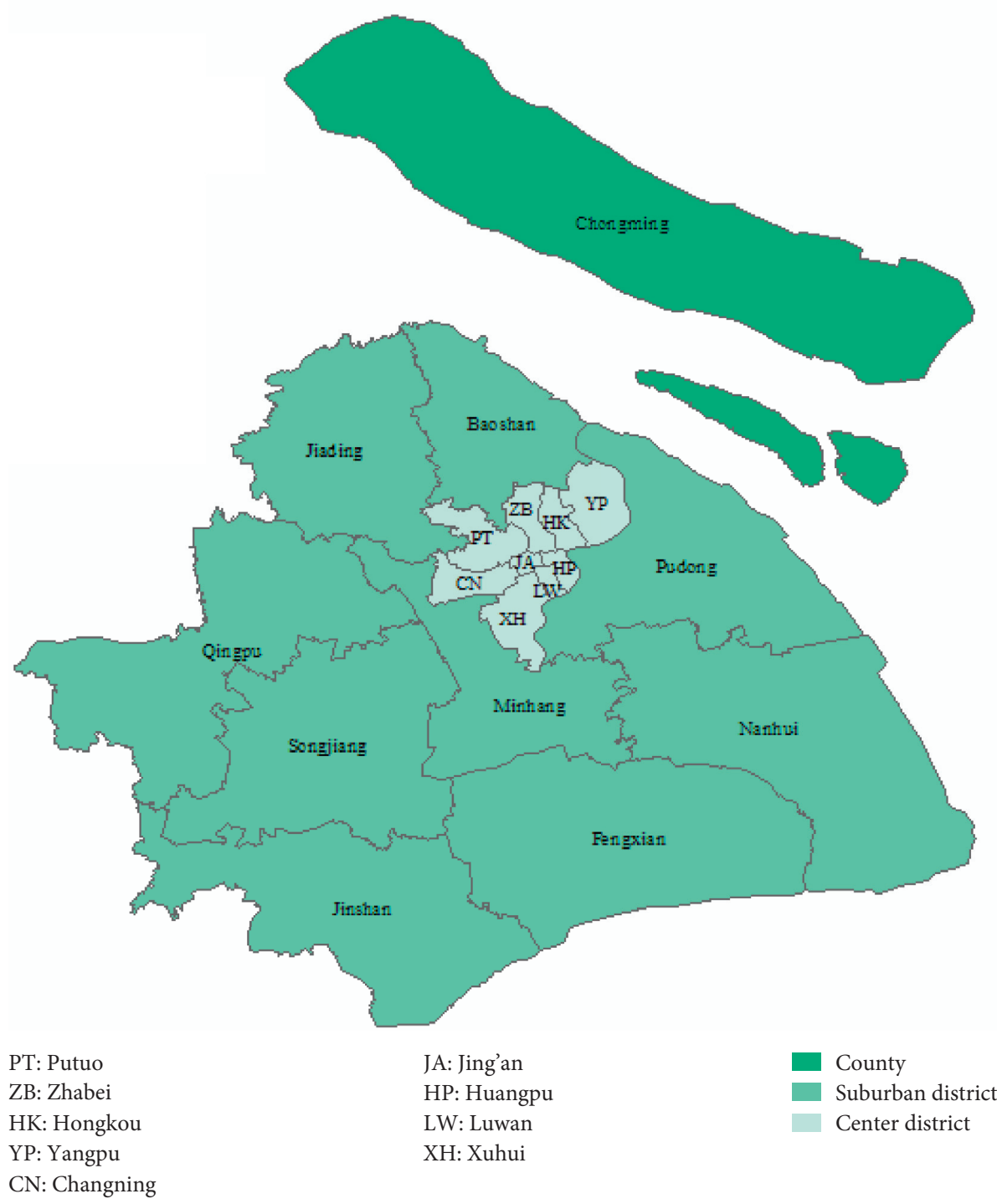

Figure 1: The distribution of center districts, suburban districts, and a county in Shanghai.

The land leasing data for industrial land use, including industrial land leasing price, area and floor area ratio of industrial land, and modes of land leasing, in Shanghai from 2007 to 2015 are collected from the official website of Shanghai Planning and Land Resources Bureau, which provides detailed information on each land leasing. Figure 2 shows the industrial land leasing in Shanghai from 2007 to 2015.

The data of the distances of the land to the city and district centers, airports, railway station, the nearest subway, nearest highway, and nearest industrial park are obtained by using the software ArcGIS. 98 industrial parks are considered in Shanghai. Figure 3 shows the subway stations and highways in Shanghai in 2015. Figure 4 shows the distribution of industrial parks in Shanghai.

\section{Mathematical Models of Industrial Land Leasing in Shanghai}

In this paper, the model used for the regression for the industrial land leasing in Shanghai is

$$
\ln \mathrm{LP}_{i t}=a+\sum_{m=1}^{M} \alpha_{m} A_{m i t}+\sum_{j=1}^{J} \beta_{j} D_{j i t}+\sum_{k=1}^{K} \gamma_{k} L_{k i t}+\mathrm{Yr} \_\mathrm{dum}+\mathrm{Dis} \_\mathrm{dum}+u_{i t},
$$




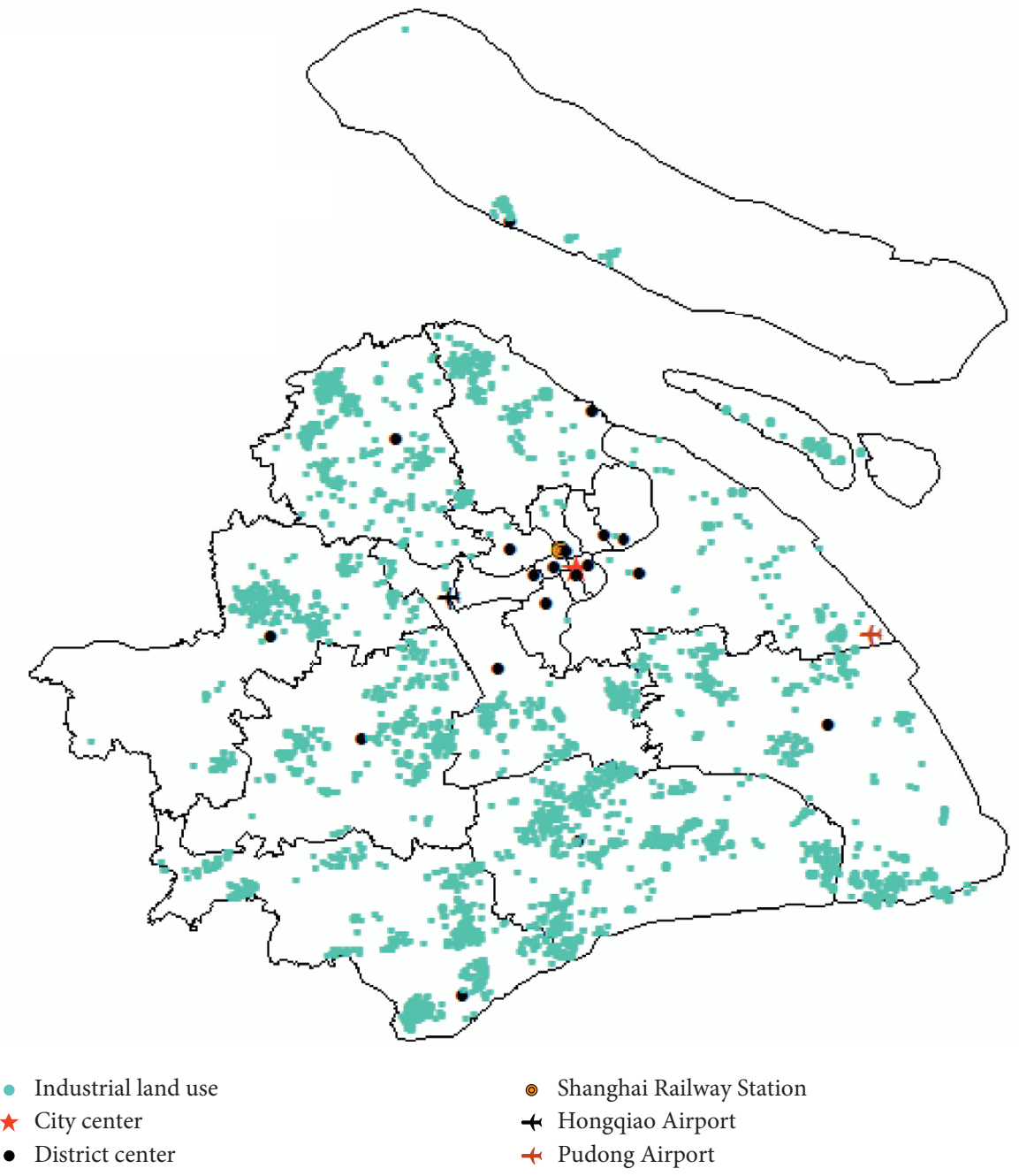

FIGURE 2: Industrial land leasing in Shanghai from 2007 to 2015.

where $\mathrm{LP}_{i t}$ is the price of every piece of leased industrial land of district $i$ in year $t, A_{\text {mit }}$ is the industrial land characteristic $A_{m}$ of district $i$ in year $t, D_{j i t}$ is the district characteristic $D_{j}$ of district $i$ in year $t, L_{k i t}$ is the location characteristic $L_{k}$ of district $i$ in year $t, M$ is the number of industrial land characteristics, $J$ is the number of district characteristics, $K$ is the number of location characteristics, $\mathrm{Yr}_{-}$dum is the year dummy variable, Dis_dum is the district dummy variable, $a$ is the constant, and $u_{i t}$ is the error term for district $i$ in year $t$. The definitions and summary statistics of the variables of land price and the influencing factors for industrial land use in Shanghai are shown in Table 1. In the table, "Obs." denotes observations, and "Std. Dev." denotes standard deviation.

Equation (1) can be written as

$$
\ln \mathrm{LP}_{i t}=a+\mathbf{a A}+u_{i t}
$$

where

$$
\begin{gathered}
\mathbf{a}=\left(\alpha_{1}, \alpha_{2}, \ldots, \alpha_{M}, \beta_{1}, \beta_{2}, \ldots, \beta_{J}, \gamma_{1}, \gamma_{2}, \ldots, \gamma_{K}, 1,1\right), \\
\mathbf{A}=\left(A_{1 i t}, A_{2 i t}, \ldots, A_{M i t}, D_{1 i t}, D_{2 i t}, \ldots, D_{J i t}, L_{1 i t}, L_{2 i t}, \ldots, L_{K i t}, Y r_{-} \text {dum, Dis_dum }\right)^{\mathrm{T}} . \\
E\left(A_{j}\left(\ln \mathrm{LP}_{i t}-a-\mathbf{a A}\right)\right)=0,
\end{gathered}
$$

Then, there are the expected value

$$
E\left(\ln \mathrm{LP}_{i t}-a-\mathbf{a A}\right)=0,
$$

and the covariance

where $A_{j}$ is the component of the vector $\mathbf{A}$.

For given sample data, we can estimate $\widehat{\mathbf{a}}$, which is the approximation of the coefficient vector $a$, and 


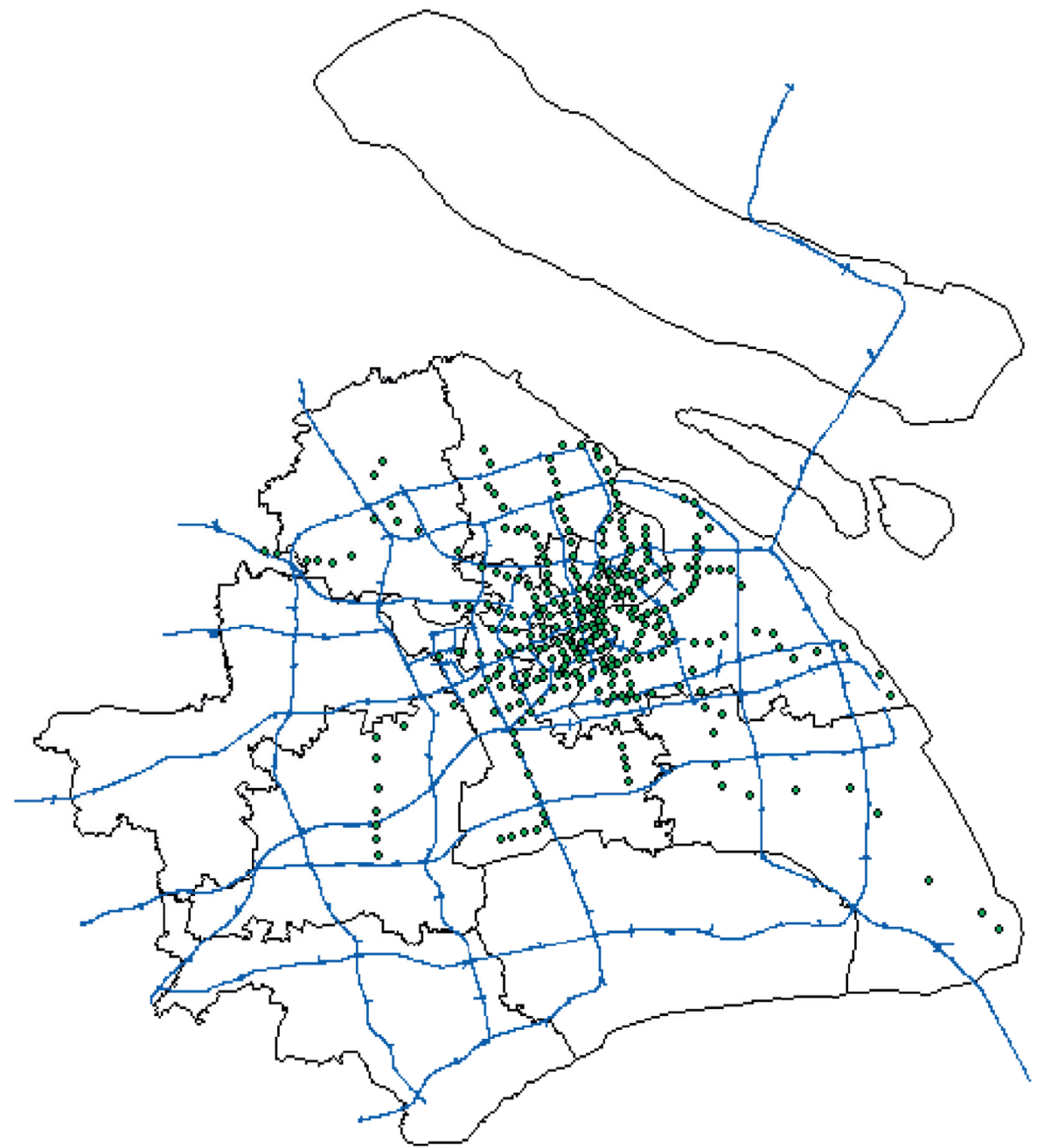

- Subway station Highway

FIgURE 3: The subway stations and highways in Shanghai in 2015.

$$
\widehat{\mathbf{a}}=\left(\widehat{a}_{1}, \widehat{a}_{2}, \ldots, \widehat{a}_{M}\right),
$$

and then, we have

$$
\begin{aligned}
\frac{1}{N} \sum_{n=1}^{N}\left(\ln L P_{i t n}-\widehat{a}-\widehat{\mathbf{a}} \mathbf{A}_{n}\right) & =0, \\
\frac{1}{N} \sum_{n=1}^{N} A_{j n}\left(\ln L P_{i t n}-\widehat{a}-\widehat{\mathbf{a}} \mathbf{A}_{n}\right) & =0,
\end{aligned}
$$

where $N$ is the sample number.

From equation (8), we have

$$
\bar{y}=\widehat{a}+\widehat{\mathbf{a}} \bar{A}_{n},
$$

then

$$
\widehat{a}=\bar{y}-\widehat{\mathbf{a}} \bar{A}_{n}
$$

where

$$
\bar{y}=\frac{1}{N} \sum_{n=1}^{N} \ln \mathrm{LP}_{i t n}
$$

Because of the arbitrariness of the number of the samples, equation (9) can be rewritten as

$$
\sum_{n=1}^{N} A_{j n}\left(\ln \mathrm{LP}_{i t n}-\widehat{a}-\widehat{\mathbf{a}} \mathbf{A}_{n}\right)=0 .
$$

Substituting equation (11) into equation (14) yields

$$
\sum_{n=1}^{N} A_{j n}\left(\ln \mathrm{LP}_{i t n}-\left(\bar{y}-\widehat{\mathbf{a}} \overline{\mathbf{A}}_{n}\right)-\widehat{\mathbf{a}} \mathbf{A}_{n}\right)=0,
$$

i.e., 


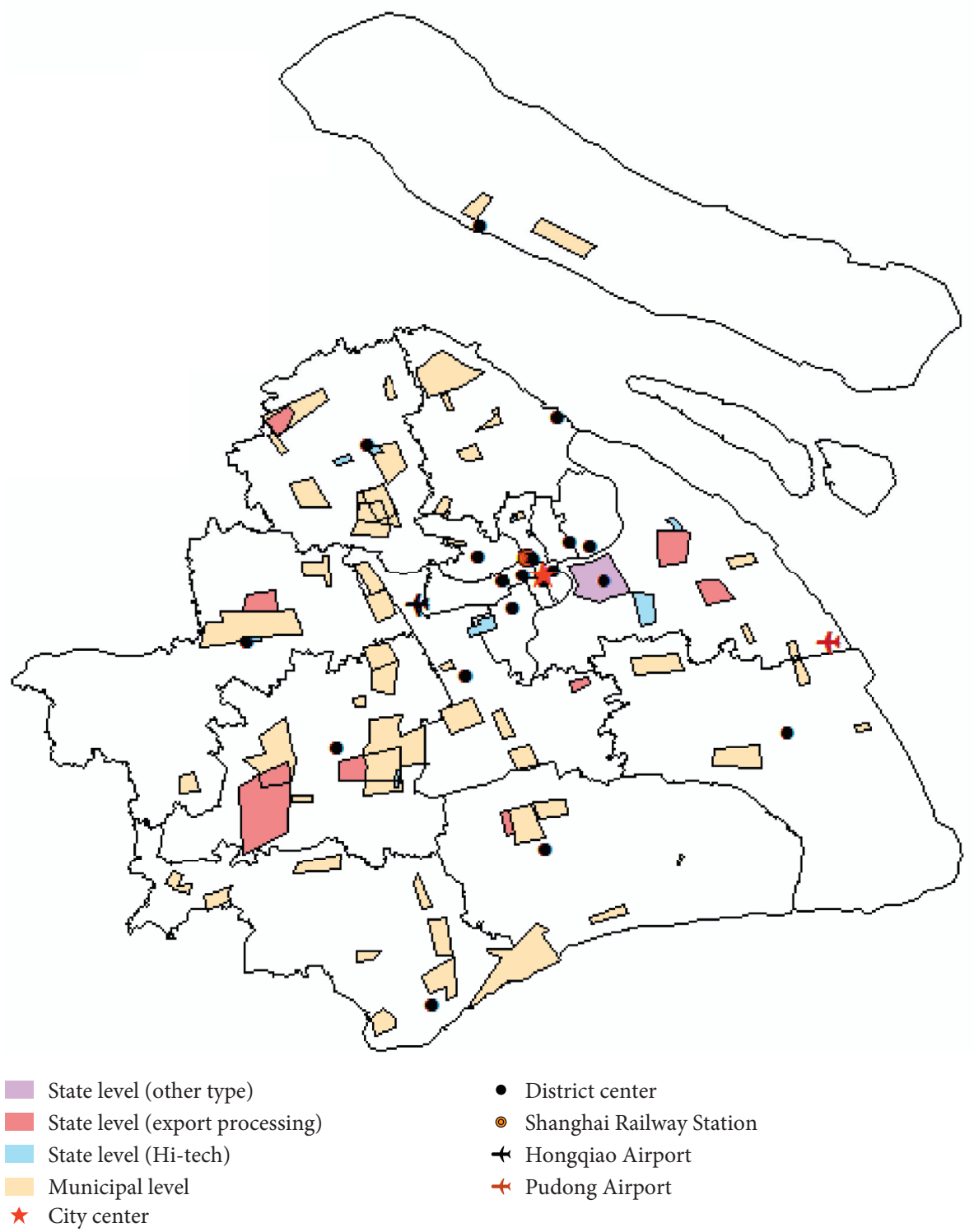

FIgURE 4: The distribution of industrial parks in Shanghai.

$$
\sum_{n=1}^{N} A_{j n}\left(\ln \operatorname{LP}_{i t n}-\bar{y}\right)=\widehat{\mathbf{a}} \sum_{n=1}^{N} A_{j n}\left(\mathbf{A}_{n}-\overline{\mathbf{A}}_{n}\right) .
$$

Then, we have

$$
\widehat{a}_{i}=\frac{\sum_{n=1}^{N} A_{j n}\left(\ln L P_{i t n}-\bar{y}\right)}{\sum_{n=1}^{N} A_{j n}\left(A_{n}-\bar{A}_{n}\right)} .
$$

The model used in this paper for the regression for industrial land area and its influencing factors is

$$
\ln \mathrm{LA}_{i t}=a+\sum_{m=1}^{M} \alpha_{v} V_{v i t}+\mathrm{Yr} \_ \text {dum }+ \text { Dis_dum }+u_{i t} \text {, }
$$

where $\mathrm{LA}_{i t}$ is the area of total leased industrial land of district $i$ in year $t, V_{\text {mit }}$ is the location characteristic $V_{m}$ of district $i$ in year $t, M$ is the number of location characteristics, Yr_dum is the year dummy variable, Dis_dum is the district dummy variable, $a$ is the constant, and $u_{i t}$ is the error term for district $i$ in year $t$. The definitions and summary statistics of the variables of land area and influencing factors for industrial land use in Shanghai are shown in Table 2.

Equation (18) can be written as

$$
\ln \mathrm{LA}_{i t}=a+\mathbf{a V}+u_{i t}
$$

where

$$
\begin{aligned}
& \mathbf{a}=\left(\alpha_{1}, \alpha_{2}, \ldots, \alpha_{M}, 1,1\right), \\
& \mathbf{V}=\left(V_{1 i t}, V_{2 i t}, \ldots, V_{\text {Mit }}, \mathrm{Yr} \text { _dum, Dis_dum }\right)^{\mathrm{T}} .
\end{aligned}
$$

Then, there are the expected value

$$
E\left(\ln \mathrm{LA}_{i t}-a-\mathbf{a V}\right)=0
$$

and the covariance 
TABLE 1: The definitions and summary statistics of the variables for industrial land price and the influencing factors.

\begin{tabular}{|c|c|c|c|c|c|}
\hline Category & Variable & Description & Obs. & Mean & Std. Dev. \\
\hline & $\ln \left(\mathrm{LP}_{i t}\right)$ & Price of every piece of leased industrial land of district $i$ in year $t$ (yuan). & 2801 & $2.16 e+07$ & $4.06 e+07$ \\
\hline$A_{1 i t}$ & $\ln \left(\right.$ Area $\left._{i t}\right)$ & Areas of the land leasing for district $i$ in year $t\left(\mathrm{~m}^{2}\right)$ & 2801 & 33645.53 & 46364 \\
\hline$A_{2 i t}$ & $\ln \left(\mathrm{FAR}_{i t}\right)$ & $\begin{array}{c}\text { Floor area ratio of the land for district } i \text { in year } t \text {. } \\
\text { Modes of land leasing for district } i \text { in year } t\end{array}$ & 2801 & 1.55 & 0.36 \\
\hline$A_{3 i t}$ & $\mathrm{MOD}_{i t}$ & $\begin{array}{l}=1 \text { when the mode is listing; } \\
=2 \text { when the mode is tender; } \\
=3 \text { when the mode is auction. } \\
\quad \text { Location of district } i\end{array}$ & 2801 & 1 & 0.07 \\
\hline$A_{4 i t}$ & $\mathrm{LOC}_{i t}$ & $\begin{array}{l}=1 \text { when } i \text { is center district; } \\
=2 \text { when } i \text { is suburban district; } \\
=3 \text { when } i \text { is county. }\end{array}$ & 2801 & 2.02 & 0.16 \\
\hline$D_{1 i t}$ & $\ln \left(\mathrm{GDP}_{i t}\right)$ & GDP for district & 2796 & $1.24 e+11$ & $1.62 e+11$ \\
\hline$D_{2 i t}$ & $\mathrm{DM}_{i t}$ & Tenure of district $\mathrm{m}$ & 2801 & 3.29 & 1.77 \\
\hline$D_{3 i t}$ & $\ln \left(\mathrm{UE}_{i t}\right)$ & Unemployment of district $i$ in year $t$ & 2712 & 12518.6 & 12959.86 \\
\hline$D_{4 i t}$ & $\ln \left(\mathrm{FI}_{i t}\right)$ & Paid-in foreign investment of di & 2801 & $5.91 e+09$ & $8.80 e+09$ \\
\hline$D_{5 i t}^{4 i t}$ & $\ln \left(\mathrm{IG}_{i t}\right)$ & Gross industrial production of & 2801 & $2.82 e+11$ & $2.33 e+11$ \\
\hline$D_{6 i t}$ & $\ln \left(\mathrm{ITA}_{i t}\right)$ & Total industrial asset of district $i$ in year $t$ (yuan). & 2801 & $2.61 e+11$ & $2.67 e+11$ \\
\hline$D_{7 i t}$ & $\ln \left(\mathrm{IE}_{i t}\right)$ & Industrial employe & 2801 & 276986.6 & 161730.4 \\
\hline$L_{1 i t}$ & $\ln \left(\mathrm{CC}_{i t}\right)$ & Distance of the land for distric & 2794 & 35853.62 & 12079.56 \\
\hline$L_{2 i t}$ & $\ln \left(\mathrm{GOV}_{i t}\right)$ & Distance of the land for district $i$ in & 2794 & 11526.89 & 7577.97 \\
\hline$L_{3 i t}$ & $\ln \left(\mathrm{SUB}_{i t}\right)$ & Distance of the land for district $i$ in year $t$ to the nearest subway $(\mathrm{m})$. & 2794 & 13622.97 & 9445.59 \\
\hline$L_{4 i t}$ & $\ln \left(\mathrm{HIGH}_{i t}\right)$ & Distance of the land for district $i$ in year $t$ to the nearest highway (m). & 2794 & 3041.43 & 3013.2 \\
\hline$L_{5 i t}$ & $\ln \left(\mathrm{IP}_{i t}\right)$ & Distance of the land for district $i$ in year $t$ to the nearest industrial park (m). & 2794 & 2184.17 & 4241.78 \\
\hline$L_{6 i t}$ & $\ln \left(\mathrm{HQ}_{i t}\right)$ & Distance of the land for district $i$ in year $t$ to Hongqiao International Airport (m). & 2794 & 33219.33 & 13292.71 \\
\hline$L_{7 i t}$ & $\ln \left(\mathrm{PD}_{i t}\right)$ & Distance of the land for district $i$ in year $t$ to Pudong International Airport (m). & 2794 & 49156.05 & 17324.87 \\
\hline$L_{8 i t}$ & $\ln \left(\mathrm{RS}_{i t}\right)$ & Distance of the land for district $i$ in year $t$ to Shanghai Railway Station (m). & 2794 & 36633.81 & 12797.27 \\
\hline
\end{tabular}

Obs. denotes observations and Std. Dev. denotes standard deviation.

TAвLE 2: The definitions and summary statistics of the variables for industrial land area and the influencing factors.

\begin{tabular}{|c|c|c|c|c|c|}
\hline Category & Variable & Description & Obs. & Mean & Std. dev. \\
\hline & $\ln \left(\mathrm{LA}_{i t}\right)$ & Area of total industrial leased land of district $i$ in year $t\left(\mathrm{~m}^{2}\right)$. & 228 & 413295.4 & 763991.2 \\
\hline$M_{1 i t}$ & $\ln \left(\mathrm{DCC}_{i t}\right)$ & Distance between district $i$ in year $t$ and People's Square (m). & 228 & 9843.57 & 11317.79 \\
\hline$M_{2 i t}$ & Subway $_{i t}$ & Number of subway stations in district $i$ in year $t$. & 228 & 10.01 & 13.31 \\
\hline$M_{3 i t}$ & Highway $_{i t}$ & Number of highway entrances and exits in district $i$ in year $t$. & 228 & 44.29 & 41.3 \\
\hline$M_{4 i t}$ & $\ln \left(\mathrm{DIP}_{i t}\right)$ & $\begin{array}{c}\text { Distance between district } i \text { in year } t \text { and the nearest industrial park (m). } \\
\text { Location of district } i \text { in year } t\end{array}$ & 228 & 401.66 & 839.16 \\
\hline$M_{5 i t}$ & $\mathrm{LOC}_{i t}$ & $\begin{array}{l}=1 \text { when } i \text { is center district; } \\
=2 \text { when } i \text { is suburban district; } \\
=3 \text { when } i \text { is county. }\end{array}$ & 228 & 1.58 & 0.59 \\
\hline
\end{tabular}

$$
E\left(V_{j}\left(\ln \mathrm{LA}_{i t}-a-\mathbf{a V}\right)\right)=0
$$

where $V_{j}$ is the component of the vector $\mathbf{V}$.

For given sample data, we can estimate $\widehat{\mathbf{a}}$, which is the approximation of the coefficient vector $a$, and

$$
\widehat{\mathbf{a}}=\left(\widehat{a}_{1}, \widehat{a}_{2}, \ldots, \widehat{a}_{M}\right),
$$

and then, we have

$$
\begin{array}{r}
\frac{1}{N} \sum_{n=1}^{N}\left(\ln \mathrm{LA}_{i t n}-\widehat{a}-\widehat{\mathbf{a}} \mathbf{V}_{n}\right)=0, \\
\frac{1}{N} \sum_{n=1}^{N} V_{j n}\left(\ln \mathrm{LA}_{i t n}-\widehat{a}-\widehat{\mathbf{a}} \mathbf{V}_{n}\right)=0 .
\end{array}
$$

From equation (25), we have

$$
\bar{y}=\widehat{a}+\widehat{\mathbf{a}} \overline{\mathbf{V}}_{n}
$$

then

$$
\widehat{a}=\bar{y}-\widehat{\mathbf{a}} \overline{\mathbf{V}}_{n}
$$

where

$$
\begin{aligned}
\bar{y} & =\frac{1}{N} \sum_{n=1}^{N} \ln \mathrm{LA}_{i t n}, \\
\overline{\mathbf{V}}_{n} & =\frac{1}{N} \sum_{n=1}^{N} \mathbf{V}_{n} .
\end{aligned}
$$

Because of the arbitrariness of the number of the samples, equation (26) can be rewritten as 


$$
\sum_{n=1}^{N} V_{j n}\left(\ln \mathrm{LA}_{i t n}-\widehat{\mathbf{a}}-\widehat{a} \mathbf{V}_{n}\right)=0 .
$$

Substituting equation (28) into equation (31) yields

$$
\sum_{n=1}^{N} V_{j n}\left(\ln \mathrm{LA}_{i t n}-\left(\bar{y}-\widehat{\mathbf{a}} \overline{\mathbf{V}}_{n}\right)-\widehat{\mathbf{a}} \mathbf{V}_{n}\right)=0
$$

i.e.,

$$
\sum_{n=1}^{N} V_{j n}\left(\ln \mathrm{LA}_{i t n}-\bar{y}\right)=\widehat{\mathbf{a}} \sum_{n=1}^{N} V_{j n}\left(\mathbf{V}_{n}-\overline{\mathbf{V}}_{n}\right)
$$

Then, we have

$$
\widehat{a}_{i}=\frac{\sum_{n=1}^{N} V_{j n}\left(\ln \mathrm{LA}_{i t n}-\bar{y}\right)}{\sum_{n=1}^{N} V_{j n}\left(V_{n}-\bar{V}_{n}\right)} .
$$

Table 3 shows the results of models for the influencing factors of industrial land leasing by the district government in Shanghai.

\section{Results and Discussions}

From the results of influencing factors of industrial land use in Shanghai in Table 3, for the land characteristics, the variable of the area of leased land is statistically very significant for land leasing by the government. The price of industrial land use increases by $0.98 \%$ when the area of leased land increases by $1 \%$. The larger is the area of industrial land use, the higher is its price.

The variable of the mode of land leasing is statistically significant for land leasing by the government. The price of industrial land use for listing is higher than that for tender. Tender is one of the modes of land leasing that invites many tenderers to participate in and allows only one bid before the deadline. Listing allows bidders to bid continuously and repeatedly before the deadline, and generally the bidder with the highest price can get the bid. The difference between tender and listing is the bid times. The industrial land price will be higher for listing than tender because in listing bidders can know others' bidding prices and as such the bidding prices can be higher than expected.

The variable of the location of the district is statistically very significant for land leasing by the government. The decrease of the grade of location of the district increases the price of industrial land leasing. The industrial land in center districts is very scarce in Shanghai, and most industrial land is in the suburban districts and the county. The industrial land price will be higher in suburban districts than that in the county. Suburban districts have better transportation systems that can help develop industry.

For the district characteristics, the variable of the GDP of the district is statistically significant for land leasing by the government. The land price of industrial land use increases by $0.23 \%$ when the GDP of the district increases by $1 \%$. If the GDP of the district is high, the government may focus on leasing industrial land for sustainable development and profits making.
The variable of the paid-in foreign investment of the district is statistically significant for land leasing by the government. The land price of industrial land use decreases by $0.1 \%$ when the paid-in foreign investment of the district increases by $1 \%$. The foreign investments promote the industry development variously, and the government intends to offer preferential prices to the companies with foreign investments.

The variable of the unemployment of the district is statistically very significant for land leasing by the government. The land price of industrial land use decreases by $1.17 \%$ when the number of the unemployment of the district increases by $1 \%$. Unemployment influences economic development, especially for the industry. Increase in unemployment adversely affects the state of industries.

The variable of the tenure of district mayor is statistically very significant for land leasing by the government. The decrease of the tenure of district mayor increases the land price of industrial land use. The district mayor may pay more attention to industrial land use in the short run for a better development of the district. Thus, the price of industrial land use increases.

The variable of the gross industrial production of the district is statistically very significant for land leasing by the government. The land price of industrial land use decreases by $0.46 \%$ when the gross industrial production of the district increases by $1 \%$. The gross industrial production increases, which shows that industrial development is very good, the district government hopes to lease industrial land at a lower price than before.

The variable of the total industrial asset of the district is statistically significant for land leasing by the government. The land price of industrial land use decreases by $0.54 \%$ when the total industrial asset increases by $1 \%$. When the total industrial asset increases, in order to use the industrial asset to promote economic development, the district government hopes to lease industrial land at a lower price than before.

As regards the number of industrial employees, the land price of industrial land use decreases by $0.44 \%$ when the number of industrial employees of the district increases by $1 \%$. When the number of industrial employees increases, in order to offer more jobs, the district government will lease industrial land at a lower price than before.

For the location characteristics, the variable of the distance between the land and Hongqiao International Airport is statistically very significant for land leasing by the government. The land price of industrial land use increases by $0.34 \%$ when the distance between the land and Hongqiao International Airport increases by $1 \%$. Hongqiao International Airport is close to the center districts in Shanghai, but the industrial land is relatively far away from the center districts.

The variable of the distance between the land and Shanghai Railway Station is statistically very significant for land leasing by the government. The land price of industrial land use decreases by $1.29 \%$ when the distance between the land and Shanghai Railway Station increases by 1\%. There are some logistics industries and other types of industries around the railway station. 
TABLE 3: The results of the models.

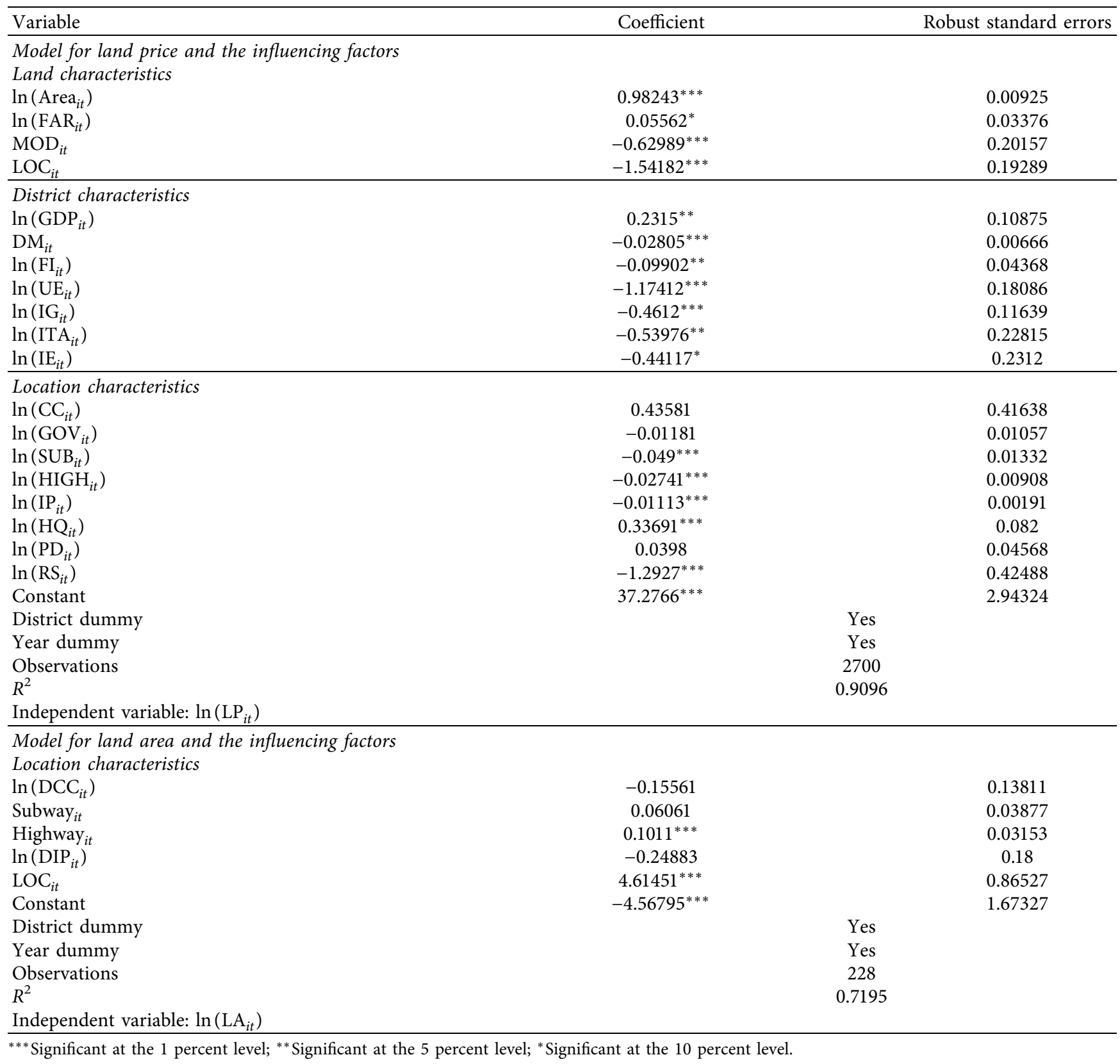

The variable of the distance between the land and the nearest subway station is statistically very significant for land leasing by the government. The land price of industrial land use decreases by $0.05 \%$ when the distance between the land and the nearest subway station increases by $1 \%$.

The variable of the distance between the land and the nearest entrance or exit of highway is statistically very significant for land leasing by the government. The land price of industrial land use decreases by $0.03 \%$ when the distance between the land and the nearest entrance or exit of highway increases by $1 \%$. The subway and highway are two important means of transportations in a large city, and the developers of industrial land prefer the locations closer to them as it enables transportation of products and external communications.
The variable of the distance between the land and the nearest industrial park is statistically very significant for land leasing by the government. The land price of industrial land use decreases by $0.01 \%$ when the distance between the land and the nearest industrial park increases by $1 \%$. The industrial parks are the places with plenty of industrial land and strong characteristics of industry; thus, the land price of industrial land use is higher when it is closer to an industrial park.

For the industrial land area and its influencing factors, the variable of the number of entrances and exits of highways is statistically very significant for industrial land area by the government. When there are more entrances and exits of highways in the district, the total land area of industrial land use increases. The government will lease more industrial 
land with the increase of the number of entrances and exits of highways. For the industrial land use, it is important to have good accessibility to the highway as it enables the transfer of goods and makes it easier for external communication. The government is more likely to lease industrial land to the districts with more entrances and exits of highways.

The variable of the location of the district is statistically very significant for land leasing by the government. The higher the grade of the location of the district, the higher is the total area of industrial land use. As the grade of the location of the district increases, the government leases more industrial land. The county is the highest grade (i.e., $\mathrm{LOC}_{i t}=3$ ), the center district is the lowest grade (i.e., $\mathrm{LOC}_{i t}=1$ ), and $\mathrm{LOC}_{i t}=2$ is for the suburban district. Hence, the county and suburban districts have more industrial land than center districts. The government prefers to lease industrial land to the suburban districts.

In summary, the land area, mode of land leasing, location of the district, GDP, paid-in foreign investment, unemployment, tenure of district mayor, gross industrial production, total industrial asset, and the distances of industrial land to Hongqiao International Airport, Shanghai Railway Station, the nearest subway station, the nearest entrance or exit of highway, and the nearest industrial park affect the industrial land price. Moreover, the number of entrances and exits of highways in the district and the location of the district affect the total industrial land area. From the analysis mentioned above, it is shown that the government is more likely to lease industrial land with larger area or listing mode. When the GDP of the district is high or the paid-in foreign investment, gross industrial production, total industrial asset, and industrial employees are under low status, the government prefers to lease industrial land. Not only the land nature and the economic development but also the political promotion affect the industrial land price and decisions made by the government. The district mayors with shorter tenures prefer to lease more industrial land. Location of the land influences the government behavior on land leasing. Suburban districts are the priority of the government for industrial land leasing. Also, the government prefers leasing industrial land near Shanghai Railway Station, subways, highways, and industrial parks. The government is more likely to lease industrial land to the districts with more entrances and exits of highways.

\section{Conclusion}

In this paper, the factors influencing industrial land leasing by the government in Shanghai are analyzed based on the district data from 2007 to 2015. The hypotheses and mathematical models for the factors influencing industrial land leasing by the government in Shanghai are proposed.

In conclusion, the land area, mode of land leasing, location of the district, GDP, paid-in foreign investment, unemployment, tenure of district mayor, gross industrial production, total industrial asset, and the distances of industrial land to Hongqiao International Airport, Shanghai Railway Station, the nearest subway station, the nearest entrance or exit of highway, and the nearest industrial park affect the industrial land price. Moreover, the number of entrances and exits of highways in the district and the location of the district affect the total industrial land area. The high transaction price of industrial land also means large profits gained by the government; therefore, the government likes leasing industrial land with higher price.

From the results, it is shown that the government in Shanghai prefers to lease industrial land with larger area or mode of listing. Also, the government tends to lease industrial land in suburban districts or counties. Meanwhile, when the GDP of the district is high or the paid-in foreign investment, gross industrial production, total industrial asset, and industrial employees are under low status, the government prefers to lease industrial land. Also, the government prefers to lease industrial land near Shanghai Railway Station, subways, highways and industrial parks. The government is more likely to lease industrial land to the districts with more entrances and exits of highways.

There are some policy implications from the results. First, the district government needs to lease industrial land when the industrial indicators are under low status, which will promote the industrial development of the city and make more comprehensive urban development. Second, the district mayors with shorter tenures prefer to lease more industrial land to focus on more sustainable development of the city. Third, the district government pays more attention on suburban districts and transportation accessibility when leasing industrial land, which will promote the formulation of industrial land pattern in the long run.

This study can promote land use planning system and sustainable urban development. Moreover, it will offer a reference for other large cities in China and other counties implementing public land ownership.

\section{Data Availability}

The data used to support the findings of this study are available within the article.

\section{Disclosure}

The research was finished when the author was a $\mathrm{PhD}$ student in the City University of Hong Kong, China.

\section{Conflicts of Interest}

The author declares that there are no conflicts of interest regarding the publication of this paper.

\section{References}

[1] J. Cheng, "Analyzing the factors influencing the choice of the government on leasing different types of land uses: evidence from Shanghai of China," Land Use Policy, vol. 90, Article ID 104303, 2020.

[2] C. Ding and E. Lichtenberg, "Land and urban economic growth in China," Journal of Regional Science, vol. 51, no. 2, pp. 299-317, 2011. 
[3] Y. Liu, F. Fang, and Y. Li, "Key issues of land use in China and implications for policy making," Land Use Policy, vol. 40, pp. 6-12, 2014.

[4] L. H. Li, "The dynamics of the Shanghai land market-an intra city analysis," Cities, vol. 28, no. 5, pp. 372-380, 2011.

[5] H. Pan and M. Zhang, "Rail transit impacts on land use: evidence from Shanghai," Transportation Research Record: Journal of the Transportation Research Board, vol. 2048, no. 1, pp. 16-25, china, 2008.

[6] M. Zhang and L. Wang, "The impacts of mass transit on land development in China: the case of Beijing," Research in Transportation Economics, vol. 40, no. 1, pp. 124-133, 2013.

[7] W. Sun, S. Zheng, and R. Wang, "The capitalization of subway access in home value: a repeat-rentals model with supply constraints in Beijing," Transportation Research Part A: Policy and Practice, vol. 80, pp. 104-115, 2015.

[8] S. Zheng, X. Hu, J. Wang, and R. Wang, "Subways near the subway: rail transit and neighborhood catering businesses in Beijing," Transport Policy, vol. 51, pp. 81-92, 2016.

[9] J. Yang, J. Chen, X. Le, and Q. Zhang, "Density-oriented versus development-oriented transit investment: decoding metro station location selection in Shenzhen," Transport Policy, vol. 51, pp. 93-102, 2016.

[10] T. Xu, M. Zhang, and P. T. Aditjandra, "The impact of urban rail transit on commercial property value: new evidence from Wuhan, China," Transportation Research Part A: Policy and Practice, vol. 91, pp. 223-235, 2016.

[11] K. Mulder, A. Troy, and R. Boumans, "The role of built, human, social, and natural capital in determining land values, and the influence of demographics upon this relationship," Spatial Economic Analysis, vol. 2, no. 2, pp. 135-156, 2007.

[12] Z. Yang, R. Ren, H. Liu, and H. Zhang, "Land leasing and local government behaviour in China: evidence from Beijing," Urban Studies, vol. 52, no. 5, pp. 841-856, 2015.

[13] E. Chernobai, M. Reibel, and M. Carney, "Nonlinear spatial and temporal effects of highway construction on house prices," The Journal of Real Estate Finance and Economics, vol. 42, no. 3, pp. 348-370, 2011.

[14] G. Tchang, "The impact of highway proximity on distribution centres' rents," Urban Studies, vol. 53, no. 13, pp. 2834-2848, 2016.

[15] R. Arabsheibani, Y. Kanani Sadat, and A. Abedini, "Land suitability assessment for locating industrial parks: a hybrid multi criteria decision-making approach using geographical information system," Geographical Research, vol. 54, no. 4, pp. 446-460, 2016. 